\title{
The Role of the Major Histocompatibility Complex Region in Cognition and Brain Structure: A Schizophrenia GWAS Follow-Up
}

\author{
James T.R. Walters, M.R.C. \\ Psych., Ph.D. \\ Dan Rujescu, M.D. \\ Barbara Franke, Ph.D. \\ Ina Giegling, Ph.D. \\ Alejandro Arias Vásquez, Ph.D. \\ April Hargreaves, M.Sc. \\ Giancarlo Russo, Ph.D. \\ Derek W. Morris, Ph.D. \\ Martine Hoogman, M.Sc. \\ Andrea Da Costa, Ph.D. \\ Valentina Moskvina, Ph.D. \\ Guillén Fernández, M.D., Ph.D. \\ Michael Gill, M.R.C.Psych., Ph.D. \\ Aiden Corvin, M.R.C.Psych., \\ Ph.D. \\ Michael C. O’Donovan, F.R.C. \\ Psych., Ph.D.

\section{Gary Donohoe, Ph.D.} \\ Michael J. Owen, F.R.C.Psych., \\ Ph.D. \\ Objective: The authors investigated the \\ effects of recently identified genome-wide \\ significant schizophrenia genetic risk var- \\ iants on cognition and brain structure. \\ Method: A panel of six single-nucleotide \\ polymorphisms (SNPs) was selected to \\ represent genome-wide significant loci \\ from three recent genome-wide associa- \\ tion studies (GWAS) for schizophrenia and \\ was tested for association with cognitive \\ measures in 346 patients with schizophre- \\ nia and 2,342 healthy comparison sub- \\ jects. Nominally significant results were \\ evaluated for replication in an indepen- \\ dent case-control sample. For SNPs show- \\ ing evidence of association with cognition, \\ associations with brain structural volumes \\ were investigated in a large independent \\ healthy comparison sample.
}

\begin{abstract}
Results: Five of the six SNPs showed no significant association with any cognitive measure. One marker in the major histocompatibility complex (MHC) region, rs6904071, showed independent, replicated evidence of association with delayed episodic memory and was significant when both samples were combined. In the combined sample of up to 3,100 individuals, this SNP was associated with widespread effects across cognitive domains, although these additional associations were no longer significant after adjusting for delayed episodic memory. In the large independent structural imaging sample, the same SNP was also associated with decreased hippocampal volume.
\end{abstract}

Conclusions: The authors identified a SNP in the MHC region that was associated with cognitive performance in patients with schizophrenia and healthy comparison subjects. This SNP, rs6904071, showed a replicated association with episodic memory and hippocampal volume. These findings implicate the $\mathrm{MHC}$ region in hippocampal structure and functioning, consistent with the role of MHC proteins in synaptic development and function. Follow-up of these results has the potential to provide insights into the pathophysiology of schizophrenia and cognition.

(Am J Psychiatry 2013; 170:877-885)
$\mathrm{I}_{\mathrm{n}}$ n recent years, the advent of genome-wide association studies (GWAS) has advanced the field of complex disease genetics, including that of major mental illnesses. The first truly large-scale GWAS in schizophrenia were published in 2009 by the International Schizophrenia Consortium (1), the Molecular Genetics of Schizophrenia study (2), and SGENE-plus (3), which also obtained additional data resulting in a sample of up to 50,000 individuals (case subjects and healthy comparison subjects). Taken together, three regions of association were identified at the genomewide significant threshold: 1) a region on chromosome 6 p22.1 that includes the major histocompatibility complex (MHC); 2) the transcription factor 4 (TCF4) locus on chromosome 18; and 3) the neurogranin (NRGN) locus on chromosome 11. Although the association signals formally implicate genomic regions rather than specific genes, the roles of NRGN and TCF4 in brain function and development (3-5) are compatible with the hypothesis that increased risk for schizophrenia is related to altered function of these genes. However, the association at 6 p22.1 is within a region of exceptionally high linkage disequilibrium (LD) spanning hundreds of genes, any of which could contain the functional susceptibility variant or variants. The identification of causative variants is made challenging by such high LD, although investigators using conditional analysis have observed at least two statistically independent associations in the MHC region (3). 
The identification of associated SNPs is only a first step toward elucidating the neurobiological pathways involved in schizophrenia. Attaining this goal requires the functional consequences of polymorphisms to be identified at the level of the protein, cell, neural circuit, or alternative human phenotypes. Studies of neurocognition and structural brain imaging offer a way of exploring the action of polymorphisms on behavioral neural circuits at the whole organism level (6). Widespread cognitive deficits are characteristic features of schizophrenia, and their amelioration is increasingly seen as central to improving the functional outcome of patients (7). In this study, we set out 1) to investigate the effects of GWAS-supported variants on cognitive phenotypes in schizophrenia patients and healthy comparison subjects and replicate any associations, and 2) to investigate the relationships between variants with cognitive effects and relevant brain structure volumes using a sample that was independent from the cognitive data collection sample. We previously reported results for rs12807809 (NRGN locus) in a subsample of the individuals included in this study (8). It should be noted that the design of this study predates the publication by the Psychiatric Genomewide Association Study Consortium of additional genome-wide significant findings in schizophrenia (9).

\section{Method}

\section{Cognition Sample Characteristics}

German sample. The German sample consisted of 346 patients with a DSM-IV diagnosis of schizophrenia and 2,342 healthy comparison subjects. Two hundred sixteen of the patients (62\%) and 545 of the comparison subjects (23\%) formed part of the SGENE-plus study (3). The patients were ascertained from mental health services in the Munich area. Exclusion criteria were a history of head injury or neurological disease. Patients, ages 18-80 years, were interviewed with the Structured Clinical Interview for DSM-IV (SCID) (10), and the interviews were rated by psychiatrists or psychologists.

Healthy comparison subjects of German descent, ages 18-80 years, were randomly selected from population registers from the Munich area. Participants underwent an extensive screening process, described previously (11), to exclude those with neurological or psychotic disorders and those who had firstdegree relatives with psychotic disorders. In the case of participants older than 60 years, the Mini-Mental State Examination (12) was employed to exclude individuals with possible cognitive impairment.

Irish replication sample. The Irish sample consisted of 377 patients with schizophrenia and 145 comparison subjects. One hundred three patients (but no comparison subjects) formed part of the International Schizophrenia Consortium study (13). Patients with schizophrenia, ages 18-65 years, were recruited from across Ireland, and the diagnosis was confirmed by trained psychiatrists using the SCID (10). Comparison subjects, ages 18-65 years, were recruited by local media advertisements. Exclusion criteria were the same as used in the German sample.

All patients with schizophrenia and comparison subjects were unrelated white Caucasians of German or Irish ancestry. All participants provided informed consent in accordance with the relevant ethics approvals.

\section{Cognitive Assessment}

The study was designed by selecting tests to represent domains of cognition that are known to be compromised in schizophrenia: IQ, episodic memory, working memory, and attention/vigilance. Given that we intended to seek replication of significant results, we selected identical or near identical tests within cognitive domains for the German and Irish samples. The number of tests and measures within each cognitive domain was limited to minimize multiple testing, mirroring our previous research (11). The German sample was used as a discovery sample, and markerphenotype combinations that were nominally significant were taken forward for replication in the Irish sample.

For the German sample, IQ was measured by the full German Wechsler Adult Intelligence Scale-Revised (WAIS-R) (14). Episodic memory was assessed using the immediate and delayed logical memory tests from the German Wechsler Memory ScaleRevised (WMS-R) (15). Verbal and spatial working memory were assessed using the digit span test from the WAIS-R and the spatial span test from the WMS-R. Attention/vigilance was assessed using the Continuous Performance Test, 3-7 Version (16). Test results were available in up to 342 patients and 2,342 comparison subjects.

For the Irish sample, IQ was measured using selected subtests (vocabulary, similarities, block design, and matrix reasoning) from the Wechsler Adult Intelligence Scale, 3rd edition (WAIS-III) (17). We measured episodic memory using the immediate and delayed logical memory tests from the Wechsler Memory Scale, 3rd edition (WMS-III) (18). Working memory was measured using the letter-number sequencing test from the WMS-III and the spatial working memory test from the Cambridge Neuropsychological Test Automated Battery (19). Attention/vigilance was measured using the three-letter condition of the Continuous Performance Test, Identical Pairs Version (20), but an insufficient number of comparison subjects completed this task, making it unavailable for this group. Test results were available for up to 377 patients and 148 comparison subjects. These procedures and the selected tests reproduce our previous research (11).

Selection of SNPs. We identified a nonredundant panel of SNPs representing all genome-wide significant signals from the combined studies of the International Schizophrenia Consortium (13), Molecular Genetics of Schizophrenia (2), and SGENE-plus (3). Among the multiple correlated signals at chromosome 6, we selected the most significantly associated variant from the International Schizophrenia Consortium and Molecular Genetics of Schizophrenia studies, rs13194053. In the German sample, we typed rs6904071, a perfect proxy for rs13194053 according to HapMap. In the SGENE-plus study, rs6932590 was the most significantly associated variant and was included in our panel. Also from that study, analysis conditioned on rs6932590 further revealed a strong, statistically independent signal at rs3131296 and, independent of both of these markers, a weak association signal at rs13219354; both of these SNPs were included in our analysis. We also selected the genome-wide significant SNPs at NRGN (rs12807809) and TCF4 (rs9960767) as reported by SGENE-plus.

We therefore analyzed the associations with cognition for a panel of six SNPs in total. The four individual MHC SNPs were not in high LD $\left(1,000\right.$ genomes, $\left.\mathrm{r}^{2}<0.8\right)$ and covered the statistically independent schizophrenia association signals that were identified in this region.

\section{Genotyping}

The SNPs were genotyped in the German sample and in a proportion of the Irish sample using the Sequenom iPLEX Gold 
system. The call rate for this genotyping was $>95 \%$ in both samples. The remainder of the Irish sample was genotyped using a Taqman SNP Genotyping Assay on a 7900HT Sequence Detection System (Applied Biosystems). The call rate for the Taqman genotyping was $>95 \%$. For all genotyping, both patient and comparison samples were in Hardy-Weinberg equilibrium for all SNPs $(\mathrm{p}>0.05)$.

\section{Statistical Analysis}

The association between markers and cognitive phenotypes was tested using linear regression, assuming an additive model, using SPSS, version 14 (21). Genotypes and patient/comparison status were entered as independent variables, and age and gender were entered as covariates when appropriate (i.e., unless scaled test scores were used). Linear regression was also performed in patient and comparison samples separately in order to examine differential effects between case and comparison subjects. Markers with nominally significant associations $(p \leq 0.05)$ in the German sample were taken forward for replication in the Irish samples. For significant markers, we also performed a casecontrol logistic regression analysis within the German discovery and Irish replication cohorts.

In addition to seeking replication, we combined the German and Irish samples to examine the association between SNPs and combined cognitive domain test scores in as large a sample as possible. We derived standardized $\mathrm{z}$ scores for each of the cognitive tests separately in each sample. These scores were then combined for equivalent tests across the two samples to give study-wide cognitive domain $\mathrm{z}$ scores. Linear regression was used in the combined sample using $\mathrm{z}$ scores as the dependent variable and genotype as the independent variable, adjusting for case status, age, and gender as appropriate.

The power of this design varies depending on the selected polymorphism and cognitive test. However, as an example, the German comparison sample has $80 \%$ power to detect a risk allele accounting for $0.34 \%$ of variance in IQ at the $5 \%$ significance threshold.

\section{Structural Imaging Analysis}

For those SNPs demonstrating a replicated association with cognition, we examined associations with cortical structure volumes that were derived from structural MRI. The imaging sample was part of the Brain Imaging Genetics project; a full description of the sample and procedures for genotyping and neuroimaging is provided in detail elsewhere (22). Briefly, 892 white Caucasian healthy young adults (369 men and 523 women; ages 18-35 years) underwent structural MRI and provided saliva samples that were genotyped using the Affymetrix GeneChip SNP, 6.0 array; genotypes were imputed using the $\mathrm{MaCH}$ software package (23). MRI acquisition was on 1.5- $\mathrm{T}(\mathrm{N}=416)$ and 3-T $(\mathrm{N}=476)$ scanners, and segmenting into gray and white matter was performed with the VBM 5.1 toolbox, version 1.19, with the SPM software package (22). Informed by the neurocognitive tests and available imaging structural phenotypes, we chose to analyze total gray matter volume and total hippocampal volume. Gray matter volume was chosen because several of the cognitive tests involve generalized cognitive functioning or are reliant on multiple, rather than specific, brain regions. Hippocampal volume was chosen as a brain structure that has specific relevance to aspects of cognition tested, particularly episodic and spatial memory. Prefrontal structural volumes would have been of interest given our cognitive battery but were unavailable for this analysis. Using linear regression, SNPs that were significantly associated with cognition were assessed for association with these brain structural volumes. The analyses were adjusted for field strength, age, and gender; the analysis of hippocampal volume was corrected for total brain volume, and the analysis of gray matter volume was corrected for total white matter volume.

\section{Results}

\section{Association With Cognition}

German sample. The results from the German data set are summarized in Table 1. As expected, patients with schizophrenia performed significantly below comparison subjects on all administered cognitive tests. Of the six SNPs examined, only one (rs6904071; equivalent by $r^{2}=1$ to rs13194053, the top hit in the International Schizophrenia Consortium and Molecular Genetics of Schizophrenia studies) showed a nominally significant association with any of the cognitive tests. For the nonsignificant SNPs, genotype mean scores for the cognitive tests of IQ, working memory, episodic memory, and attention/vigilance are presented in Tables S1-S5 in the data supplement that accompanies the online edition of this article.

The detailed results for the significantly associated marker, rs6904071, in the German sample are presented in Table 2 (and as part of Figure 1). Nominally significant associations were found with IQ $(B=1.060, p=0.046)$, spatial working memory $(\mathrm{B}=0.448, \mathrm{p}=0.049)$, delayed episodic memory $(\mathrm{B}=1.488, \mathrm{p}=0.011)$, and attention $(\mathrm{B}=0.15$, $\mathrm{p}=0.001$ ). Notably, for all cognitive tests, individuals homozygous for the schizophrenia risk $\mathrm{G}$ allele performed more poorly than heterozygotes, who in turn performed more poorly than nonrisk A homozygotes.

Irish replication sample. The SNP rs6904071, which showed significant associations with cognition in the German sample, was taken forward for replication (Table 3). Assuming a conservative one-tailed alpha of $0.0125(0.05 / 4$ [ $4=$ number of tests that were significant in the German sample]), the delayed episodic memory test displayed significant replication (WMS delayed logical memory; see Tables 2 and 3 and Figure 1). This association was in the same allelic direction as in the German sample, that is, the schizophrenia risk $G$ allele was associated with worse performance in delayed episodic memory.

The detailed results of the separate patient and comparison group analyses in both the German and Irish samples are provided in Table S6 in the online data supplement.

We also examined whether this SNP, rs6904071, was associated with schizophrenia in the two samples. The SNP was nominally associated with schizophrenia in the Irish sample (odds ratio=1.49, $\mathrm{p}=0.023$ ) but was not significantly associated with schizophrenia in the German sample (odds ratio=1.11, $\mathrm{p}=0.33$ ). Notably, the allelic direction of association was the same in both samples and mirrored that in the original GWAS studies (although there was sample overlap as outlined above).

Combined sample. Table 4 summarizes the results for the combined analysis. This analysis confirms an association 
TABLE 1. Results of Linear Regression of Genome-Wide Significant Single-Nucleotide Polymorphism (SNP) Associations With Cognitive Domains $^{\mathrm{a}}$

\begin{tabular}{|c|c|c|c|c|c|c|c|c|c|c|c|c|}
\hline \multirow[b]{2}{*}{ SNP } & \multicolumn{2}{|c|}{$\begin{array}{c}\text { General Cognitive } \\
\text { Ability }\end{array}$} & \multicolumn{2}{|c|}{$\begin{array}{l}\text { Verbal Working } \\
\text { Memory }\end{array}$} & \multicolumn{2}{|c|}{$\begin{array}{c}\text { Spatial Working } \\
\text { Memory }\end{array}$} & \multicolumn{2}{|c|}{$\begin{array}{l}\text { Immediate Episodic } \\
\text { Memory }\end{array}$} & \multicolumn{2}{|c|}{$\begin{array}{c}\text { Delayed Episodic } \\
\text { Memory }\end{array}$} & \multicolumn{2}{|c|}{$\begin{array}{l}\text { Attention/ } \\
\text { Vigilance }\end{array}$} \\
\hline & B & $\mathrm{p}$ & B & $\mathrm{p}$ & B & $\mathrm{p}$ & B & $\mathrm{p}$ & B & $\mathrm{p}$ & B & $\mathrm{p}$ \\
\hline rs6904071 & 1.060 & 0.046 & 0.242 & 0.077 & 0.448 & 0.049 & 0.553 & 0.284 & 1.488 & 0.011 & 0.150 & 0.001 \\
\hline rs13219354 & 0.968 & 0.138 & 0.033 & 0.847 & 0.200 & 0.474 & -0.275 & 0.663 & 0.525 & 0.465 & 0.102 & 0.063 \\
\hline rs3131296 & -0.107 & 0.866 & -0.044 & 0.790 & -0.369 & 0.219 & 0.563 & 0.403 & 0.615 & 0.423 & 0.107 & 0.067 \\
\hline rs6932590 & 0.909 & 0.056 & 0.131 & 0.284 & 0.362 & 0.081 & -0.335 & 0.473 & 0.002 & 0.997 & 0.077 & 0.053 \\
\hline rs9960767 & 0.537 & 0.555 & 0.405 & 0.085 & -0.100 & 0.794 & -0.201 & 0.814 & 0.177 & 0.856 & -0.127 & 0.073 \\
\hline rs12807809 & -1.03 & 0.060 & -0.104 & 0.460 & -0.064 & 0.791 & 0.309 & 0.570 & -0.276 & 0.656 & 0.003 & 0.950 \\
\hline
\end{tabular}

a Positive regression coefficient indicates schizophrenia risk allele associated with worse performance on cognitive test. Nominally significant $p$ values were taken forward for replication.

b For loci with minor allele frequencies $<0.1$, the analysis was redone by grouping together minor allele and heterozygote genotype groups. The results remained unchanged and none were significant.

TABLE 2. Detailed Results for rs6904071 in the German Sample in a Study of Single-Nucleotide Polymorphism Associations With Cognitive Domains

\begin{tabular}{|c|c|c|c|c|c|c|c|c|c|c|c|c|}
\hline \multirow{2}{*}{$\begin{array}{l}\text { Cognitive } \\
\text { Function }\end{array}$} & \multirow[b]{2}{*}{ Test or Subscale ${ }^{a}$} & \multirow[b]{2}{*}{ Sample } & \multirow[b]{2}{*}{$\mathrm{N}$} & \multicolumn{2}{|c|}{ AA } & \multicolumn{2}{|c|}{ AG } & \multicolumn{2}{|c|}{ GG } & \multirow{2}{*}{$\begin{array}{l}\text { Regression } \\
\text { Coefficient }^{\mathrm{b}}\end{array}$} & \multirow[b]{2}{*}{$95 \% \mathrm{Cl}$} & \multirow[b]{2}{*}{$p^{c}$} \\
\hline & & & & Mean & SD & Mean & SD & Mean & SD & & & \\
\hline \multirow{2}{*}{$\begin{array}{l}\text { General } \\
\text { cognitive } \\
\text { ability }\end{array}$} & \multirow[t]{2}{*}{ Full-scale IQ } & Patients & 342 & 106.5 & 17.8 & 100.8 & 17.7 & 99.3 & 18.5 & \multirow[t]{2}{*}{1.060} & \multirow[t]{2}{*}{$0.020-2.101$} & \multirow[t]{2}{*}{0.046} \\
\hline & & Comparison & 2,244 & 114.5 & 13.9 & 113.8 & 14.5 & 113.0 & 14.5 & & & \\
\hline $\begin{array}{l}\text { Verbal working } \\
\text { memory }\end{array}$ & WAIS digit span & Patients & $\begin{array}{r}342 \\
244\end{array}$ & $\begin{array}{l}16.4 \\
147\end{array}$ & $\begin{array}{l}4.6 \\
40\end{array}$ & 14.0 & 3.5 & $\begin{array}{l}13.3 \\
14 ?\end{array}$ & 3.7 & 0.242 & -0.026 to 0.511 & 0.077 \\
\hline \multirow{2}{*}{$\begin{array}{l}\text { Spatial working } \\
\text { memory }\end{array}$} & \multirow{2}{*}{$\begin{array}{l}\text { WMS-R spatial } \\
\text { span }\end{array}$} & Patients & 239 & 18.5 & 3.73 & 15.3 & 2.98 & 14.91 & 3.40 & \multirow[t]{2}{*}{0.448} & \multirow[t]{2}{*}{$0.002-0.895$} & \multirow[t]{2}{*}{$0.04 \mathrm{C}$} \\
\hline & & Comparison & 399 & 17.8 & 3.79 & 17.3 & 3.11 & 17.11 & 3.43 & & & \\
\hline \multirow{2}{*}{$\begin{array}{l}\text { Immediate } \\
\text { episodic } \\
\text { memory }\end{array}$} & \multirow{2}{*}{$\begin{array}{l}\text { WMS-R immediate } \\
\text { logical memory }\end{array}$} & Patients & 240 & 29.2 & 8.6 & 24.8 & 8.2 & 23.9 & 9.0 & \multirow[t]{2}{*}{0.553} & \multirow[t]{2}{*}{-0.461 to 1.566} & \multirow[t]{2}{*}{0.284} \\
\hline & & Comparison & 400 & 31.6 & 7.4 & 30.6 & 6.5 & 30.7 & 6.6 & & & \\
\hline \multirow{2}{*}{$\begin{array}{l}\text { Delayed episodic } \\
\text { memory }\end{array}$} & \multirow{2}{*}{$\begin{array}{l}\text { WMS-R delayed } \\
\text { logical memory }\end{array}$} & Patients & 239 & 30.0 & 11.5 & 28.8 & 9.4 & 25.8 & 10.5 & \multirow[t]{2}{*}{1.488} & \multirow[t]{2}{*}{$0.341-2.635$} & \multirow[t]{2}{*}{0.011} \\
\hline & & Comparison & 400 & 36.7 & 9.1 & 34.7 & 6.6 & 34.1 & 7.4 & & & \\
\hline \multirow{2}{*}{$\begin{array}{l}\text { Attention/ } \\
\text { vigilance }\end{array}$} & CPT-IP (3-7 & Patients & 346 & 4.59 & 0.67 & 4.28 & 0.83 & 4.10 & 0.95 & 0.150 & $0.063-0.236$ & 0.001 \\
\hline & version) & Comparison & 517 & 4.90 & 0.49 & 4.85 & 0.56 & 4.71 & 0.58 & & & \\
\hline
\end{tabular}

${ }^{a}$ WAIS=Wechsler Adult Intelligence Scale; CPT-IP=Continuous Performance Test, Identical Pairs Version; WMS-R=German Wechsler Memory Scale-Revised. Raw scores are provided for WMS-R tests; all other scores are scaled.

${ }^{\mathrm{b}} \mathrm{B}$ coefficient with respect to schizophrenia risk allele $(\mathrm{G})$ adjusted for age and sex as appropriate.

c Nominally significant association results taken forward for replication in Irish sample.

between rs6904071 and five of the six cognitive tests at a nominally significant level. Notably, the combined analysis results indicate association with delayed episodic memory and attention/vigilance at a level that would survive adjustment for multiple testing of all six SNPs and six cognitive tests $(p<0.0014)$. Table 4 also outlines the results for schizophrenia patients and healthy comparison subjects considered separately. rs6904071 was associated with performance on cognitive measures in both patients and comparison subjects.

Because the replicated finding and the most significant association in the combined analysis was for delayed episodic memory, we repeated the combined analysis for the other cognitive domains while adjusting for delayed episodic memory to investigate whether the other cognitive associations were independent of the association with this cognitive domain. The sample for the adjusted analysis was smaller (maximum $\mathrm{N}=1,161$ ), but rs6904071 remained significantly associated with the same cognitive domains in this sample in unadjusted analyses. However, after adjusting for delayed episodic memory performance, none of the other cognitive domains remained significantly associated (see Table S7 in the online data supplement for results of this analysis).

The association of rs6904071 genotype with demographic and clinical variables in both samples is summarized in Table S8 in the online data supplement. No significant differences in age, gender distribution, and education by genotype were found in patients or comparison subjects in either sample. Furthermore, in patients, no significant differences were observed between genotype groups in antipsychotic medication dosage in either sample.

\section{Structural Imaging}

As the only significant SNP to emerge from the analysis with cognition, rs6904071 alone was taken forward to the structural imaging analysis. This SNP was significantly 
associated with total hippocampal volume $(\mathrm{B}=0.080$; 95\% confidence interval $[\mathrm{CI}]=0.006-0.154, \mathrm{p}=0.035)$ and with total gray matter volume $(\mathrm{B}=-5.93 ; 95 \% \mathrm{CI}=-0.37$ to $-11.49, \mathrm{p}=0.036$ ). The schizophrenia risk allele, which was associated with worse cognition, was associated with smaller hippocampal volume, which was the predicted direction of association. The finding for gray matter was in the counterintuitive direction, in that the risk allele was associated with increased gray matter volume.

\section{Discussion}

At the time this study was conducted, the polymorphisms that we examined represented all of the genomewide significant common variants thus far reported for schizophrenia, with the exception of rs1344706 at ZNF804A, on which we have previously reported (11). In taking the GWAS results forward to examine their effects on cognition, we sought to overcome the limitations of previous cognitive and genetic studies by testing SNP associations with a priori selected cognitive tests in large samples of healthy subjects and schizophrenia patients and by seeking replication of results in a sample with equivalent tests. Despite this design, we failed to show any association with cognition for five of the six schizophrenia risk SNPs tested. TCF4 and $N R G N$ are good candidate genes for cognition given their putative roles in neurodevelopment and the processes involved in cognition $(4,5)$. It is therefore of particular interest that neither of these risk variants was associated with cognitive performance in this study. Given that our study had the power to detect an allelic effect accounting for $0.3 \%$ of variance in IQ in the German comparison sample alone, it is unlikely that these alleles have effects of this magnitude on human cognition, although we cannot exclude smaller effects.

This lack of effect at the behavioral and cognitive level for the majority of the tested SNPs is perhaps to be expected, given recent evidence that the overlap between the genetics of schizophrenia and cognition is less than previously proposed and that the majority of the genetic variance for schizophrenia does not overlap with that of cognition $(24,25)$. This is in keeping with other research suggesting a limited role in cognition for common candidate variants for schizophrenia (26).

The strongest evidence we obtained for an association between schizophrenia risk alleles and cognitive measures was for SNP rs6904071, in the MHC region. The association was in the predicted direction - that is, the schizophrenia risk allele was associated with poorer cognition. The replicated association of this SNP with cognition was for the domain of delayed episodic memory. That phenotype was evaluated in the German and Irish samples using precisely the same test (delayed logical memory). The lack of replication for other cognitive domains may be due to a lack of formal equivalence between the domain tests in the two samples or as a result of the relatively smaller size of
FIGURE 1. Delayed Episodic Memory Scores in German and Irish Patients With Schizophrenia and Healthy Comparison Subjects, by rs6904071 Genotype ${ }^{\mathrm{a}}$

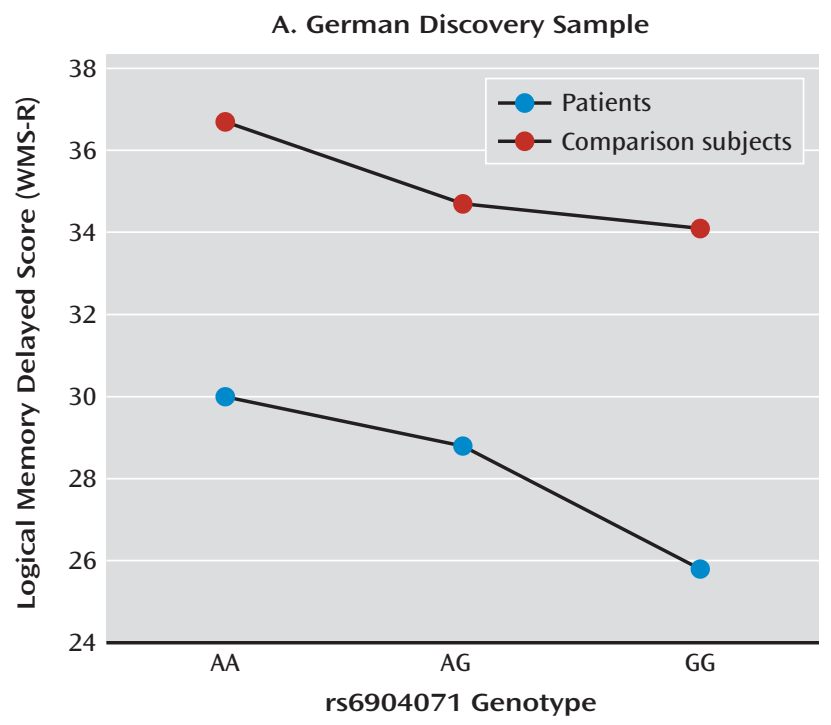

B. Irish Replication Sample

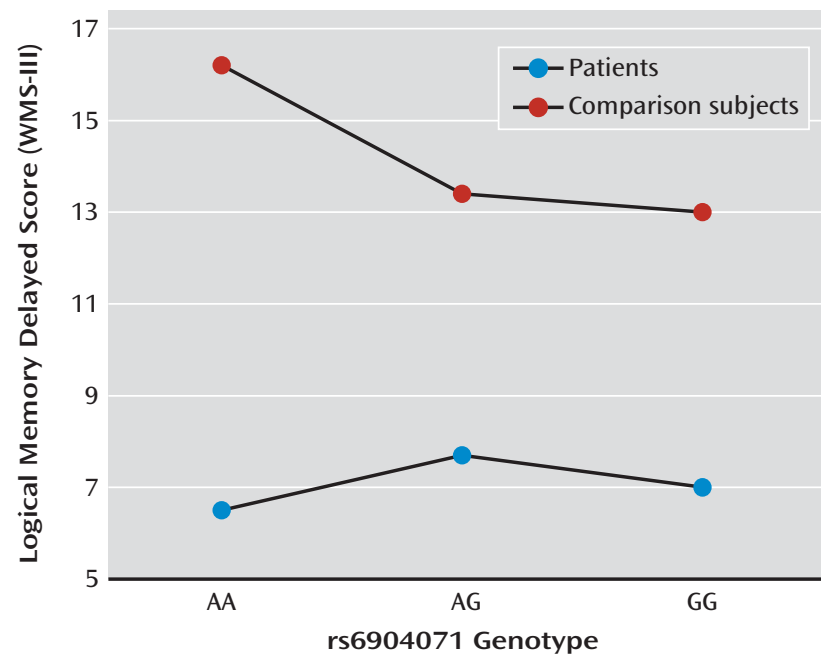

a WMS-R= German Wechsler Memory Scale-Revised; WMS-III=Wechsler Adult Intelligence Scale, 3rd edition.

the Irish replication sample. To counter the sample size limitation, we combined data across both samples using $\mathrm{z}$ scores for equivalent tests, and we demonstrated nominal association with five of the six cognitive domains in the combined sample. However, in follow-up adjusted analyses, the significant associations for the other cognitive domains could have been explained by the association with delayed episodic memory. This would suggest that the effect on cognition of whatever functional variant is tagged by rs6904071 is through biological pathways involved in episodic memory. It follows that the same pathways could be involved in the action of this polymorphism on elevated schizophrenia risk, although the possibility of pleiotropy cannot be ruled out by our analysis. 
TABLE 3. Results for rs6904071 in the Irish Replication Sample in a Study of Single-Nucleotide Polymorphism Associations With Cognitive Domains

\begin{tabular}{|c|c|c|c|c|c|c|c|c|c|c|c|c|}
\hline \multirow{2}{*}{$\begin{array}{l}\text { Cognitive } \\
\text { Function }\end{array}$} & \multirow[b]{2}{*}{ Test or Subscale ${ }^{a}$} & \multirow[b]{2}{*}{ Sample } & \multirow[b]{2}{*}{$\mathrm{N}$} & \multicolumn{2}{|c|}{ AA } & \multicolumn{2}{|c|}{$\mathrm{AG}$} & \multicolumn{2}{|c|}{ GG } & \multirow{2}{*}{$\begin{array}{l}\text { Regression } \\
\text { Coefficient }^{b}\end{array}$} & \multirow[b]{2}{*}{$95 \% \mathrm{Cl}$} & \multirow[b]{2}{*}{$p^{c}$} \\
\hline & & & & Mean & SD & Mean & SD & Mean & SD & & & \\
\hline $\begin{array}{l}\text { General } \\
\text { cognitive } \\
\text { ability }\end{array}$ & $\begin{array}{l}\text { Abbreviated } \\
\text { full-scale IQ }\end{array}$ & $\begin{array}{l}\text { Patients } \\
\text { Comparison }\end{array}$ & $\begin{array}{l}300 \\
148\end{array}$ & $\begin{array}{r}92.5 \\
131.0\end{array}$ & $\begin{array}{l}19.3 \\
11.5\end{array}$ & $\begin{array}{r}91.5 \\
121.5\end{array}$ & $\begin{array}{l}18.0 \\
14.9\end{array}$ & $\begin{array}{r}90.5 \\
121.8\end{array}$ & $\begin{array}{l}18.1 \\
14.6\end{array}$ & 1.389 & -1.592 to 4.369 & 0.180 \\
\hline $\begin{array}{l}\text { Spatial } \\
\text { working } \\
\text { memory }\end{array}$ & $\begin{array}{l}\text { Cambridge } \\
\text { Neuropsychological } \\
\text { Test Automated } \\
\text { Battery spatial } \\
\text { working memory task }\end{array}$ & $\begin{array}{l}\text { Patients } \\
\text { Comparison }\end{array}$ & $\begin{array}{l}365 \\
140\end{array}$ & $\begin{array}{r}-1.08 \\
0.26\end{array}$ & $\begin{array}{l}0.92 \\
0.83\end{array}$ & $\begin{array}{r}-0.97 \\
0.26\end{array}$ & $\begin{array}{l}1.29 \\
0.75\end{array}$ & $\begin{array}{r}-0.96 \\
0.17\end{array}$ & $\begin{array}{l}1.34 \\
0.84\end{array}$ & 0.005 & -0.188 to 0.199 & 0.478 \\
\hline $\begin{array}{l}\text { Delayed } \\
\text { episodic } \\
\text { memory }\end{array}$ & $\begin{array}{l}\text { WMS-III logical } \\
\text { memory delayed }\end{array}$ & $\begin{array}{l}\text { Patients } \\
\text { Comparison }\end{array}$ & $\begin{array}{l}377 \\
145\end{array}$ & $\begin{array}{r}6.5 \\
16.2\end{array}$ & $\begin{array}{l}3.3 \\
1.6\end{array}$ & $\begin{array}{r}7.7 \\
13.4\end{array}$ & $\begin{array}{l}3.2 \\
2.5\end{array}$ & $\begin{array}{r}7.0 \\
13.0\end{array}$ & $\begin{array}{l}3.3 \\
2.6\end{array}$ & 0.575 & $0.083-1.067$ & 0.011 \\
\hline $\begin{array}{l}\text { Attention/ } \\
\text { vigilance }\end{array}$ & CPT-IP (3 letters) & $\begin{array}{l}\text { Patients } \\
\text { Comparison }\end{array}$ & $\begin{array}{r}257 \\
\mathrm{n} / \mathrm{a}\end{array}$ & 2.27 & 1.5 & 1.97 & 0.87 & 1.95 & 1.04 & 0.031 & -0.209 to 0.271 & 0.399 \\
\hline
\end{tabular}

TABLE 4. Association of rs6904071 With z Scores of Cognitive Domains in Combined German and Irish Samples

\begin{tabular}{|c|c|c|c|c|c|c|c|c|c|c|c|}
\hline \multirow[b]{2}{*}{$\begin{array}{l}\text { Cognitive } \\
\text { Function }\end{array}$} & \multirow[b]{2}{*}{ Participants } & \multirow[b]{2}{*}{$\mathrm{N}$} & \multicolumn{3}{|c|}{ Comparison Subjects } & \multicolumn{3}{|c|}{ Patients } & \multicolumn{3}{|c|}{ Combined Sample ${ }^{\mathrm{a}}$} \\
\hline & & & $\begin{array}{l}\text { (Regression } \\
\text { Coefficient) }\end{array}$ & $95 \% \mathrm{Cl}$ & $\mathrm{p}$ & B & $95 \% \mathrm{Cl}$ & $\mathrm{p}$ & B & $95 \% \mathrm{Cl}$ & $\mathrm{p}$ \\
\hline $\begin{array}{l}\text { General } \\
\text { cognitive } \\
\text { ability }^{b}\end{array}$ & $\begin{array}{l}\text { Patients } \\
\text { Comparison }\end{array}$ & $\begin{array}{r}642 \\
2,392\end{array}$ & 0.072 & $0.006-0.139$ & 0.034 & 0.113 & $\begin{array}{c}-0.040 \text { to } \\
0.265\end{array}$ & 0.149 & 0.08 & $0.018-0.141$ & 0.011 \\
\hline $\begin{array}{l}\text { Verbal } \\
\text { working } \\
\text { memory }\end{array}$ & $\begin{array}{l}\text { Patients } \\
\text { Comparison }\end{array}$ & $\begin{array}{r}711 \\
2389\end{array}$ & 0.053 & $\begin{array}{c}-0.020 \text { to } \\
0.126\end{array}$ & 0.158 & 0.145 & $0.018-0.271$ & 0.025 & 0.072 & $0.009-0.136$ & 0.026 \\
\hline $\begin{array}{l}\text { Spatial } \\
\text { working } \\
\text { memory }\end{array}$ & $\begin{array}{l}\text { Patients } \\
\text { Comparison }\end{array}$ & $\begin{array}{l}604 \\
539\end{array}$ & 0.073 & $\begin{array}{l}-0.057 \text { to } \\
0.203\end{array}$ & 0.269 & 0.025 & $\begin{array}{c}-0.178 \text { to } \\
0.127\end{array}$ & 0.743 & 0.027 & $\begin{array}{c}-0.073 \text { to } \\
0.127\end{array}$ & 0.596 \\
\hline $\begin{array}{l}\text { Immediate } \\
\text { episodic } \\
\text { memory }\end{array}$ & $\begin{array}{l}\text { Patients } \\
\text { Comparison }\end{array}$ & $\begin{array}{l}620 \\
545\end{array}$ & 0.093 & $\begin{array}{l}-0.027 \text { to } \\
0.213\end{array}$ & 0.128 & 0.104 & $\begin{array}{c}-0.035 \text { to } \\
0.243\end{array}$ & 0.141 & 0.098 & $0.006-0.189$ & 0.036 \\
\hline $\begin{array}{l}\text { Delayed } \\
\text { episodic } \\
\text { memory }\end{array}$ & $\begin{array}{l}\text { Patients } \\
\text { Comparison }\end{array}$ & $\begin{array}{l}616 \\
545\end{array}$ & 0.156 & $0.042-0.270$ & 0.007 & 0.180 & $0.042-0.317$ & 0.01 & 0.166 & $0.077-0.255$ & $2.66 \times 10^{-4}$ \\
\hline $\begin{array}{l}\text { Attention/ } \\
\text { vigilance }\end{array}$ & $\begin{array}{l}\text { Patients } \\
\text { Comparison }\end{array}$ & $\begin{array}{l}603 \\
517\end{array}$ & 0.148 & $0.040-0.257$ & 0.007 & 0.180 & $0.010-0.349$ & 0.038 & 0.164 & $0.063-0.265$ & 0.001 \\
\hline
\end{tabular}

a Adjusted for diagnostic status.

b Full-scale IQ in German sample and abbreviated IQ in Irish sample.

c Wechsler Adult Intelligence Scale digit span in German sample and letter-number sequencing in Irish sample.

d Wechsler Memory Scale spatial span in German sample and Cambridge Neuropsychological Test Automated Battery spatial working memory in Irish sample.

e Immediate logical memory in both samples.

${ }^{f}$ Delayed logical memory in both samples.

g 3-7 version of the Continuous Performance Test used in German sample and three-letter version of the Continuous Performance Test, Identical Pairs Version, used in Irish sample.

By an order of magnitude, delayed episodic memory was the most strongly associated cognitive domain, and rs6904071 was associated with performance in this domain in both patients and comparison subjects. Performance on the delayed logical memory test is known to be sensitive to hippocampal pathology and resection $(27,28)$ and is correlated with hippocampal volume in clinical samples (29) as well as in the relatives of patients with schizophrenia (30). Thus, our finding of association with decreased hippocampal volume links rs6904071 to both structure and function. Given the known prior relationship between the cognitive and structural phenotype, the fact that we observed an association with hippocampal structure in a sample independent of the sample from which the cognitive measures were obtained provides independent validation of the associations. This finding adds to the evidence suggesting an association between SNPs in the MHC region and structural brain volumes, including the hippocampus $(31,32)$. 
rs6904071 was also associated with increased gray matter volume. The interpretation of this result is not as straightforward as the hippocampal finding and may well be a false positive finding as a result of chance. While schizophrenia is typically associated with decreased gray matter volume, other neurodevelopmental disorders, such as autism, may be characterized by increased gray matter volume, particularly in individuals with low IQ (33). An inverse relationship between structural volume and performance has been posited for various cognitive abilities (34), although whether this proves relevant for the association between rs6904071 and gray matter volume will require further exploration.

The associated SNP (rs6904071) lies within the extended $\mathrm{MHC}$ region on chromosome 6 . The prospect of this region harboring genetic risk variants for schizophrenia has long been recognized (35) and has some support in research (9, 36, 37). Despite this, the association between the MHC region and schizophrenia has been criticized as likely a result of population stratification (38). To counter this criticism, our study used a subset of participants in the German sample for whom genome-wide genotyping was available $(\mathrm{N}=1,171)$ and derived principal components using the Eigenstrat method (39). The association between rs6904071 and cognition was robust to the addition of one, two, or three principal components, none of which affected the estimated effect size for any of the cognitive tests (see Table S9 in the online data supplement). This indicates that population stratification is unlikely to explain these results, particularly when taken together with the finding of replication in an independent sample.

It is possible that the association between schizophreniaassociated markers at the MHC region and cognition and brain structure may implicate altered immune function in each of these phenotypes. Of over 160 genes in the MHC region, roughly $30 \%$ are immune related, and the region has been implicated in numerous immune-related diseases (40). The possible link between immune function and schizophrenia is reinforced by evidence suggesting co-segregation between a range of autoimmune conditions and schizophrenia (41).

However, in addition to immune-related explanations, there are alternative potential mechanisms underpinning the associations we have observed. Our signal lies within the MHC class I region. MHC class I proteins have an established role in adaptive immunity, but findings also point to an involvement of this complex in synaptic development and plasticity (42). Specifically, MHC class I influences hippocampal long-term potentiation (43), providing a potential link between rs6904071, altered hippocampal structure and function, and a major mechanism of learning and memory. Furthermore, MHC class I protein expression co-localizes postsynaptically with postsynaptic density protein 95 in dendrites of the hippocampus and has been found to play a role in synaptic morphology and function (44). In the absence of evidence that the associations we have observed reflect altered function at MHC class I, we mention this as a caution against assuming that the association implicates immunity. Given the LD structure at this region, identifying the direct pathophysiological implications of the genetic associations will prove challenging.

To summarize, in following up genome-wide significant schizophrenia loci, we have demonstrated that the most significant risk variant from the International Schizophrenia Consortium and Molecular Genetics of Schizophrenia studies $(1,2)$ is associated with cognition, specifically delayed episodic memory. We have also both replicated this finding and shown that the same allele is associated with hippocampal volume in a manner consistent with known relationships between cognition and hippocampal structure. The associated polymorphism is in the MHC region, but until the source of the association signal is more precisely identified, it is impossible to adjudicate between several theoretically plausible mechanisms linking the association to schizophrenia and cognition in the MHC. The ultimate resolution of this question has the potential to indicate novel mechanisms linking cognitive deficits to schizophrenia.

Received Feb. 16, 2012; revisions received Oct. 16, 2012, and Jan. 8, 2013; accepted Jan. 14, 2013 (doi: 10.1176/appi.ajp.2013. 12020226). From the Medical Research Council (MRC) Centre for Neuropsychiatric Genetics and Genomics, Neuroscience and Mental Health Research Institute, Cardiff University, Cardiff, Wales; Molecular and Clinical Neurobiology and Department of Psychiatry, LudwigMaximilians University, Munich; the Departments of Human Genetics, Psychiatry, and Cognitive Neuroscience, Donders Institute for Brain, Cognition, and Behavior, Radboud University Nijmegen Medical Center, Nijmegen, the Netherlands; Neuropsychiatric Genetics Research Group, Department of Psychiatry and Institute of Molecular Medicine and Trinity Institute of Neuroscience, Trinity College, Dublin; Functional Genomics Center Zurich, University of Zurich, Switzerland; and the Department of Language and Genetics, Max Planck Institute for Psycholinguistics, Nijmegen. Address correspondence to Prof. O’Donovan (odonovanmc@cf.ac.uk).

The authors report no financial relationships with commercial interests.

Genotyping of the German sample was funded by grants from the MRC and Wellcome Trust. Recruitment and genotyping of the Irish sample was supported by the Wellcome Trust and Science Foundation Ireland. Recruitment of the patients from Munich, Germany, was partially supported by GlaxoSmithKline.

The authors thank all patients and staff who contributed to this study as well as Sabine Kooijman for sample collection for the Nijmegen Brain Imaging Genetics study and Angelien Heister for organizing molecular analysis of this sample. The Nijmegen Brain Imaging Genetics study is supported by the Dutch National Organization for Scientific Research and the Dutch Brain Foundation. The authors also thank Prof. John Waddington, Prof. Ted Dinan, Prof. Eadbhard O'Callaghan, Prof. Kieran Murphy, and Dr. F. Anthony O'Neil for their role in the recruitment of the Irish patient sample. Dr. Walters is supported by a Cardiff University Neuroscience and Mental Health Research Institute fellowship. The Cardiff investigators are supported by the MRC Centre for Neuropsychiatric Genetics and Genomics and by the MRC Program (grant G0800509). Dr. Donohoe is supported by a Health Research Board grant. 


\section{References}

1. Purcell SM, Wray NR, Stone JL, Visscher PM, O'Donovan MC, Sullivan PF, Sklar P; International Schizophrenia Consortium: Common polygenic variation contributes to risk of schizophrenia and bipolar disorder. Nature 2009; 460:748-752

2. Shi J, Levinson DF, Duan J, Sanders AR, Zheng Y, Pe'er I, Dudbridge F, Holmans PA, Whittemore AS, Mowry BJ, Olincy A, Amin F, Cloninger CR, Silverman JM, Buccola NG, Byerley WF, Black DW, Crowe RR, Oksenberg JR, Mirel DB, Kendler KS, Freedman R, Gejman PV: Common variants on chromosome 6p22.1 are associated with schizophrenia. Nature 2009; 460:753-757

3. Stefansson H, Ophoff RA, Steinberg S, Andreassen OA, Cichon S, Rujescu D, Werge T, Pietiläinen OP, Mors O, Mortensen PB, Sigurdsson E, Gustafsson O, Nyegaard M, Tuulio-Henriksson A, Ingason A, Hansen T, Suvisaari J, Lonnqvist J, Paunio T, Børglum AD, Hartmann A, Fink-Jensen A, Nordentoft M, Hougaard D, Norgaard-Pedersen B, Böttcher Y, Olesen J, Breuer R, Möller HJ, Giegling I, Rasmussen HB, Timm S, Mattheisen M, Bitter I, Réthelyi JM, Magnusdottir BB, Sigmundsson T, Olason P, Masson G, Gulcher JR, Haraldsson M, Fossdal R, Thorgeirsson TE, Thorsteinsdottir $U$, Ruggeri M, Tosato S, Franke B, Strengman E, Kiemeney LA, Melle I, Djurovic S, Abramova L, Kaleda V, Sanjuan J, de Frutos R, Bramon E, Vassos E, Fraser G, Ettinger U, Picchioni M, Walker N, Toulopoulou T, Need AC, Ge D, Yoon JL, Shianna KV, Freimer NB, Cantor RM, Murray R, Kong A, Golimbet V, Carracedo A, Arango C, Costas J, Jönsson EG, Terenius L, Agartz I, Petursson $\mathrm{H}$, Nöthen MM, Rietschel M, Matthews PM, Muglia P, Peltonen L, St Clair D, Goldstein DB, Stefansson K, Collier DA; Genetic Risk and Outcome in Psychosis (GROUP): Common variants conferring risk of schizophrenia. Nature 2009; 460:744-747

4. Blake DJ, Forrest M, Chapman RM, Tinsley CL, O’Donovan MC, Owen MJ: TCF4, schizophrenia, and Pitt-Hopkins syndrome. Schizophr Bull 2010; 36:443-447

5. Hayashi Y: Long-term potentiation: two pathways meet at neurogranin. EMBO J 2009; 28:2859-2860

6. Walters JT, Owen MJ: Endophenotypes in psychiatric genetics. Mol Psychiatry 2007; 12:886-890

7. Green MF, Kern RS, Heaton RK: Longitudinal studies of cognition and functional outcome in schizophrenia: implications for MATRICS. Schizophr Res 2004; 72:41-51

8. Donohoe G, Walters J, Morris DW, Da Costa A, Rose E, Hargreaves A, Maher K, Hayes E, Giegling I, Hartmann AM, Möller HJ, Muglia P, Moskvina V, Owen MJ, O’Donovan MC, Gill M, Corvin A, Rujescu D: A neuropsychological investigation of the genome wide associated schizophrenia risk variant NRGN rs12807809. Schizophr Res 2011; 125:304-306

9. Schizophrenia Psychiatric Genome-Wide Association Study (GWAS) Consortium: Genome-wide association study identifies five new schizophrenia loci. Nat Genet 2011; 43:969-976

10. First MB, Spitzer RL, Gibbon M, Williams JB: Structured Clinical Interview for DSM-IV Axis I Disorders-Patient Edition. New York, Biometrics Research Department, New York State Psychiatric Institute, 1995

11. Walters JTR, Corvin A, Owen MJ, Williams H, Dragovic M, Quinn EM, Judge R, Smith DJ, Norton N, Giegling I, Hartmann AM, Möller HJ, Muglia P, Moskvina V, Dwyer S, O’Donoghue T, Morar B, Cooper M, Chandler D, Jablensky A, Gill M, Kaladjieva L, Morris DW, O’Donovan MC, Rujescu D, Donohoe G: Psychosis susceptibility gene ZNF804A and cognitive performance in schizophrenia. Arch Gen Psychiatry 2010; 67:692-700

12. Folstein MF, Folstein SE, McHugh PR: Mini-Mental-Status-Test, German Version. Weinheim, Beltz, 1990

13. Purcell SM, Wray NR, Stone JL, Visscher PM, O’Donovan MC, Sullivan PF, Sklar P; International Schizophrenia Consortium: Common polygenic variation contributes to risk of schizophrenia and bipolar disorder. Nature 2009; 460:748-752
14. Tewes U: HAWIE-R Hamburg-Wechsler Intelligenztest für Erwachsene. Goettingen, Hogrefe, 1991

15. Härting C, Markowitsch HJ, Neufeld H, Calabrese P, Deisinger K, Kessler J: Wechsler Gedächtnistest-Revidierte Fassung. Bern, Huber, 2000

16. Nuechterlein K, Asarnow R: 3-7 Continuous Performance Test. Los Angeles, University of California, 2004

17. Wechsler D: Wechsler Adult Intelligence Scale, 3rd ed. New York, Psychological Corporation, 1997

18. Wechsler D: The Wechsler Memory Scale, 3rd ed. San Antonio, Tex, Psychological Corp (Harcourt), 1997

19. Cognition C: Cambridge Neuropsychological Test Automated Battery, expedio version (CANTABexpedio). Cambridge, Cambridge Cognition, 2003

20. Cornblatt BA, Risch NJ, Faris G, Friedman D, Erlenmeyer-Kimling L: The Continuous Performance Test, identical pairs version (CPT-IP): I. new findings about sustained attention in normal families. Psychiatry Res 1988; 26:223-238

21. SPSS: Statistical package for the social sciences (SPSS), version 14.0. Chicago, SPSS, 2005

22. Bralten J, Arias-Vásquez A, Makkinje R, Veltman JA, Brunner HG Fernández G, Rijpkema M, Franke B: Association of the Alzheimer's gene SORL1 with hippocampal volume in young, healthy adults. Am J Psychiatry 2011; 168:1083-1089

23. Li Y, Willer CJ, Ding J, Scheet P, Abecasis GR: MaCH: using sequence and genotype data to estimate haplotypes and unobserved genotypes. Genet Epidemiol 2010; 34:816-834

24. Toulopoulou T, Goldberg TE, Mesa IR, Picchioni M, Rijsdijk F, Stahl D, Cherny SS, Sham P, Faraone SV, Tsuang M, Weinberger DR, Seidman LJ, Murray RM: Impaired intellect and memory: a missing link between genetic risk and schizophrenia? Arch Gen Psychiatry 2010; 67:905-913

25. Fowler T, Zammit S, Owen MJ, Rasmussen F: A populationbased study of shared genetic variation between premorbid IQ and psychosis among male twin pairs and sibling pairs from Sweden. Arch Gen Psychiatry 2012; 69:460-466

26. Need AC, Attix DK, McEvoy JM, Cirulli ET, Linney KL, Hunt P, Ge D, Heinzen EL, Maia JM, Shianna KV, Weale ME, Cherkas LF, Clement G, Spector TD, Gibson G, Goldstein DB: A genome-wide study of common SNPs and CNVs in cognitive performance in the CANTAB. Hum Mol Genet 2009; 18:4650-4661

27. Miller LA, Lai R, Munoz DG: Contributions of the entorhinal cortex, amygdala and hippocampus to human memory. Neuropsychologia 1998; 36:1247-1256

28. Naugle RI, Chelune GJ, Cheek R, Lüders H, Awad IA: Detection of changes in material-specific memory following temporal lobectomy using the Wechsler Memory Scale-Revised. Arch Clin Neuropsychol 1993; 8:381-395

29. Apostolova LG, Morra JH, Green AE, Hwang KS, Avedissian C, Woo E, Cummings JL, Toga AW, Jack CR Jr, Weiner MW, Thompson PM; Alzheimer's Disease Neuroimaging Initiative: Automated 3D mapping of baseline and 12-month associations between three verbal memory measures and hippocampal atrophy in 490 ADNI subjects. Neuroimage 2010; 51 : 488-499

30. O'Driscoll GA, Florencio PS, Gagnon D, Wolff ALV, Benkelfat C, Mikula L, Lal S, Evans AC: Amygdala-hippocampal volume and verbal memory in first-degree relatives of schizophrenic patients. Psychiatry Res 2001; 107:75-85

31. Agartz I, Brown AA, Rimol LM, Hartberg CB, Dale AM, Melle I, Djurovic S, Andreassen OA: Common sequence variants in the major histocompatibility complex region associate with cerebral ventricular size in schizophrenia. Biol Psychiatry 2011; 70 : 696-698

32. Stein JL, Medland SE, Vasquez AA, Hibar DP, Senstad RE, Winkler AM, Toro R, Appel K, Bartecek R, Bergmann $\varnothing$, Bernard M, Brown AA, Cannon DM, Chakravarty MM, Christoforou A, Domin 
M, Grimm O, Hollinshead M, Holmes AJ, Homuth G, Hottenga JJ, Langan C, Lopez LM, Hansell NK, Hwang KS, Kim S, Laje G, Lee $\mathrm{PH}$, Liu X, Loth E, Lourdusamy A, Mattingsdal M, Mohnke S, Maniega SM, Nho K, Nugent AC, O'Brien C, Papmeyer M, Pütz B, Ramasamy A, Rasmussen J, Rijpkema M, Risacher SL, Roddey JC, Rose EJ, Ryten M, Shen L, Sprooten E, Strengman E, Teumer A, Trabzuni D, Turner J, van Eijk K, van Erp TG, van Tol MJ, Wittfeld K, Wolf C, Woudstra S, Aleman A, Alhusaini S, Almasy L, Binder EB, Brohawn DG, Cantor RM, Carless MA, Corvin A, Czisch M, Curran JE, Davies G, de Almeida MA, Delanty N, Depondt C, Duggirala R, Dyer TD, Erk S, Fagerness J, Fox PT, Freimer NB, Gill $M$, Göring HH, Hagler DJ, Hoehn D, Holsboer F, Hoogman M, Hosten N, Jahanshad N, Johnson MP, Kasperaviciute D, Kent JW Jr, Kochunov P, Lancaster JL, Lawrie SM, Liewald DC, Mandl R, Matarin M, Mattheisen M, Meisenzahl E, Melle I, Moses EK, Mühleisen TW, Nauck M, Nöthen MM, Olvera RL, Pandolfo M, Pike GB, Puls R, Reinvang I, Rentería ME, Rietschel M, Roffman JL, Royle NA, Rujescu D, Savitz J, Schnack HG, Schnell K, Seiferth $\mathrm{N}$, Smith C, Steen VM, Valdés Hernández MC, Van den Heuvel M, van der Wee NJ, Van Haren NE, Veltman JA, Völzke H, Walker R, Westlye LT, Whelan CD, Agartz I, Boomsma DI, Cavalleri GL, Dale AM, Djurovic S, Drevets WC, Hagoort P, Hall J, Heinz A, Jack CR Jr, Foroud TM, Le Hellard S, Macciardi F, Montgomery GW, Poline JB, Porteous DJ, Sisodiya SM, Starr JM, Sussmann J, Toga AW, Veltman DJ, Walter H, Weiner MW, Bis JC, Ikram MA, Smith AV, Gudnason V, Tzourio C, Vernooij MW, Launer LJ, DeCarli C, Seshadri S, Andreassen OA, Apostolova LG, Bastin ME, Blangero J, Brunner HG, Buckner RL, Cichon S, Coppola G, de Zubicaray GI, Deary IJ, Donohoe G, de Geus EJ, Espeseth T, Fernández G, Glahn DC, Grabe HJ, Hardy J, Hulshoff Pol HE, Jenkinson M, Kahn RS, McDonald C, Mclntosh AM, McMahon FJ, McMahon KL, Meyer-Lindenberg A, Morris DW, Müller-Myhsok B, Nichols TE, Ophoff RA, Paus T, Pausova Z, Penninx BW, Potkin SG, Sämann PG, Saykin AJ, Schumann G, Smoller JW, Wardlaw JM, Weale ME, Martin NG, Franke B, Wright MJ, Thompson PM; Alzheimer's Disease Neuroimaging Initiative; EPIGEN Consortium; IMAGEN Consortium; Saguenay Youth Study Group; Cohorts for Heart and Aging Research in Genomic Epidemiology Consortium; Enhancing Neuro Imaging Genetics through Meta-Analysis Consortium: Identification of common variants associated with human hippocampal and intracranial volumes. Nat Genet 2012; 44:552-561

33. Freitag CM, Luders E, Hulst HE, Narr KL, Thompson PM, Toga AW, Krick C, Konrad C: Total brain volume and corpus callosum size in medication-naive adolescents and young adults with autism spectrum disorder. Biol Psychiatry 2009; 66: 316-319

34. Kanai R, Rees G: The structural basis of inter-individual differences in human behaviour and cognition. Nat Rev Neurosci 2011; 12:231-242

35. McGuffin P: Is schizophrenia an HLA-associated disease? Psychol Med 1979; 9:721-728

36. Wei J, Hemmings GP: The NOTCH4 locus is associated with susceptibility to schizophrenia. Nat Genet 2000; 25:376-377

37. Li T, Li Z, Chen P, Zhao Q, Wang T, Huang K, Li J, Li Y, Liu J, Zeng Z, Feng G, He L, Shi Y: Common variants in major histocompatibility complex region and TCF4 gene are significantly associated with schizophrenia in Han Chinese. Biol Psychiatry 2010; 68:671-673

38. McClellan J, King M-C: Genomic analysis of mental illness: a changing landscape. JAMA 2010; 303:2523-2524

39. Price AL, Patterson NJ, Plenge RM, Weinblatt ME, Shadick NA, Reich D: Principal components analysis corrects for stratification in genome-wide association studies. Nat Genet 2006; 38 : 904-909

40. Wellcome Trust Case Control Consortium: Genome-wide association study of 14,000 cases of seven common diseases and 3,000 shared controls. Nature 2007; 447:661-678

41. Eaton WW, Byrne M, Ewald H, Mors O, Chen C-Y, Agerbo E, Mortensen PB: Association of schizophrenia and autoimmune diseases: linkage of Danish national registers. Am J Psychiatry 2006; 163:521-528

42. Shatz CJ: MHC class I: an unexpected role in neuronal plasticity. Neuron 2009; 64:40-45

43. Huh GS, Boulanger LM, Du H, Riquelme PA, Brotz TM, Shatz CJ: Functional requirement for class I MHC in CNS development and plasticity. Science 2000; 290:2155-2159

44. Goddard CA, Butts DA, Shatz CJ: Regulation of CNS synapses by neuronal MHC class I. Proc Natl Acad Sci USA 2007; 104: 6828-6833 